Article

\title{
Macroeconomic Determinants of Islamic Banking Products in Indonesia
}

\author{
Nur Setyowati ${ }^{1,2}$ (D) \\ 1 International Business Department, National Kaohsiung University of Science and Technology, \\ Kaohsiung 807, Taiwan; setyowati.first@gmail.com; Tel.: +886-968-524-706 \\ 2 Accounting Department, Politeknik Negeri Semarang, Semarang 50275, Indonesia
}

Received: 10 April 2019; Accepted: 14 May 2019; Published: 3 June 2019

\begin{abstract}
The purpose of the study was to investigate which factors determine saving and financing in Islamic banks in Indonesia by using Gregory-Hansen cointegration, vector error correction mode (VECM), Granger causality, and the impulse response function. The results disclose the existence of a long-running cointegrating relationship with a structural break in the deposit and financing case to the consumer price index, industrial production, interest rate, exchange rate, and Jakarta Islamic Index. Most of the structural breaks appeared in January 2006 and April 2007 for both deposit and financing, revealing the first stage of the financial crisis. Any short-term deviation between deposit and financing will give rise to a stable relationship in the long term. In the short-term, there is bidirectional causality between deposits and industrial production and between the consumer price index and financing. This finding shows that real activity, as measured by industrial production, is a highly determinant factor of Islamic bank deposits, while inflation, as measured by the customer price index, is the determinant factor of Islamic bank financing. Our results also suggest that a mix of dynamic behaviors from both Islamic bank savings and financing was revealed in response to the shock of the macroeconomic variable, giving better insight for the government and stakeholders into Indonesian Islamic banking.
\end{abstract}

Keywords: Islamic bank; saving; financing; consumer price index; industrial production; interest rate; exchange rate; Jakarta Islamic index

\section{Introduction}

Along with the rapid pace of economic growth, there have been developments in the banking system in Indonesia. The larger Islamic population and its need for a financial intermediary based on both religious beliefs and the direct Indonesian law of banking (Number 7,1992$)$ led to the creation of the dual banking system, which is both a conventional banking system and a Sharia banking system. The Sharia banking system, or Islamic banking, refers to banks based on Islamic (Sharia) laws and practices, which completely prohibit interest activity and the trade of elements that are prohibited by Islamic culture. Banks operating under the Islamic tenets are expected to generate and disburse funds under specified agreements, including profit-sharing agreements, whereby the profits that arise from the use of funds are shared between the banks and the borrowers on the one hand and the banks and the depositors on the other hand. In other words, borrowers and lenders engaged in Islamic financial transactions are basically involved in venture financing, and therefore share the associated profits and risks (Solarin et al. 2018).

There are similar main activities between commercial banks and Islamic banks, whereby they both offer saving and lending to the customers. However, while commercial banks are highly dependent on loans to create more profit via interest rates, Islamic banks follow Islamic ethics and use loan-financing options in which interest rates cannot be charged. In the dual banking system, the ability of both 
conventional and Islamic banks to attract customers and survive under economically uncertain conditions will determine their banking business.

Although the market share of Islamic banking in Indonesia was relatively small at around 5\% in 2016, the industry showed a faster growth rate compared to conventional banks. For many years, the Islamic banking sector has been growing at a double-digit pace, reaching its peak in 2011 after recording a $50 \%$ increase in total assets. Since then, the percentage growth rate has started to decline to $34.1 \%, 24.2 \%$, and $12.4 \%$ in 2012, 2013, and 2014, respectively. Macroeconomic turmoil has also been attributed to this declining growth rate, and in turn has significantly impacted the overall growth of the industry. This included electricity and gasoline price inflation toward the end of 2014, a significant depreciation of the Indonesian Rupiah throughout 2015, drops in the Indonesian stock index, and social-political issues related to the seemingly weakening anti-graft body (Alwyni 2011).

The negative consequences of adverse macroeconomic events saw a slowdown in Islamic banking. Theoretically, the relations between the macroeconomic indicators that influence bank activity can be explained by industrial production, the stock market, interest rates, inflation, and the exchange rate. Industrial production and the stock market reflect business cycles and the economic conditions within the country. Exposed business cycles will decrease the banks' intermediary function within this sector. Therefore, interest-rate risks associated with changes in market interest rates constitute a central source of market risk for banks. Excessive exchange-rate volatility impairs economic and financial stability in a country, and was found to have played a significant role in inducing banking crises (Lindgren et al. 1996). An increased rate of inflation diminishes the real rates of return on bank assets and induces loan rationing (Bohachova 2008).

Past and recent empirical literature on Islamic bank deposits was studied in Solarin et al. (2018), Haron and Azmi (2008) and Kasri and Kassim (2009), whereas literature on financing can be discovered in the works of Adebola et al. (2011) and Karim et al. (2017). However, the limited literature available on Islamic banking deposits and financing does not provide better insight into the determining factors. There has been a limited focus on this area, with the literature only looking at saving or financing, not both. However, there is a need for comparable views within these two activities in Islamic banking, which led us to examine the factors that determine both saving and financing in Islamic banks.

The aim of this study is to investigate the factors determining Islamic banking savings and financing in Indonesia from January 2004 to June 2018. We contribute to the literature in four important ways. First, we compare the factors that influence both Islamic banking savings and financing in Indonesia. Second, we investigate both long-term and short-term determining factors of saving and financing in Islamic banks. Third, we measure the structural breaks in the data, as there is a possibility of the Islamic banking system being exposed by another economic shock. Fourth, we investigate the dynamic responses to see how each variable change determines the others.

Using Indonesia as the case study brings the advantage of being able to see the different behaviors of Islamic bank customers in emerging countries. In addition, the investigation of banks in Indonesia, the biggest Muslim country in the world, could provide a better understanding of Muslim behavior, as Mobin and Masih (2016) stated that religious beliefs can affect the banking-related decisions of Muslim customers. Lastly, it is important to investigate the influences of different factors in Islamic banking that could enhance its ability to stand up against conventional banks, which still hold the majority of the banking capital in Indonesia.

The following sections of our paper are divided into four parts. The next section presents a brief review of the related literature, followed by the data and the empirical model that is used. Then, the empirical results and discussion are presented, and lastly, the conclusions are given.

\section{Literature Review}

Economic literature on bank savings has mostly determined the relationship between savings and interest rates. Since interest rates are restricted under Muslim law, the positive and negative effects of interest rates are influenced by religious beliefs. Interest rates do not have any significant effect on 
Islamic bank deposits, as has been found by several researchers (see, for example, Tariq and Masih 2016; Kassim et al. 2009; Sukmana and Kassim 2010; Hassan 2016). Others have found positive relations between bank savings and interest rates (see, for example, Solarin et al. 2018; Loayza and Shankar 2000; Athukorala and Tsai 2003; Ojeaga et al. 2016; Ostadi and Sarlak 2014; Eriemo 2014; Siaw and Lawer 2015; Mushtaq and Siddiqui 2017). In their findings, Mushtaq and Siddiqui (2017) concluded that interest rates, which are forbidden in Islam, have significant positive impacts on bank deposits in non-Muslim countries both in the long-term and short-term; however, in Muslim countries, because of the religious restriction on interest rates, both in the long-term and short-term, people do not care about increases or decreases in interest rates while depositing money in banks.

Other related macroeconomic factors that influence bank savings and deposits, such as inflation, gross domestic product (GDP), and the money supply variable role, have been addressed in several studies. Inflation was found to have a negative effect on bank savings (see, e.g., Loayza and Shankar 2000; Athukorala and Tsai 2003; Ostadi and Sarlak 2014; Siaw and Lawer 2015; Akhtar et al. 2011). Moreover, Loayza and Shankar (2000) revealed that the income per capita and the share of agriculture in GDP have positive effects on savings, while financial development and the dependency ratio have negative effects on saving in India. The money supply effect was found by Haron and Azmi (2008) and Ostadi and Sarlak (2014).

Research on Islamic banking deposits and savings was done by Haron and Azmi (2008), who also uncovered the roles of the Islamic bank profit rate, the base lending rate, the Kuala Lumpur composite index, the consumer price index, and the gross domestic product, which have significant impacts on deposits. They further determined that returns on deposits and inflation have negative impacts on bank deposits, while the composite index and money supply have positive impacts on bank deposits. Kasri and Kassim (2009) investigated the factors that affect savings in Islamic banks in Indonesia and revealed that higher Islamic deposits are significantly correlated with higher rates of return, and that lower interest rates are associated with higher Islamic deposits.

Solarin et al. (2018) investigated the determinants of Islamic banking deposits in Malaysia and concluded that the industrial production index and the real interest rates of fixed and saving deposits have positive impacts on several components of Islamic banking deposits and the total deposits of Islamic banks, while the real interest rates on deposits have a negative impact in commercial banks. However, the effects of both the Sharia index and the real exchange rate on Islamic banking deposits are mixed. The results also suggest that displaced commercial risks exist in the deposits of Islamic banks, as those deposits are affected by conventional banks' interest rates.

Although the economic literature is rich with different aspects of loans and credit and their determinants in conventional banks, very few studies have addressed Islamic bank financing or lending. Particularly, bank loans in conventional banking are affected by macroeconomic and microeconomic variables. Macroeconomic factors such as the money supply, interest rate, economic growth, inflation rate, exchange rate, and stock market index have been widely studied in the economic literature (see, e.g., Kim and Moreno 1994; Pruteanu-Podpiera 2007; Ibrahim 2006; Pham 2015), while the microeconomic variables that have been considered most often are bank size, bank capitalization, collateral security, capital ratio, provision for losses, liquidity, and asset quality (Karim et al. 2017; Chernykh and Theodossiou 2011; Cowling and Westhead 1996).

A relatively limited number of studies has investigated the value of Islamic bank financing. Another study by Adebola et al. (2011) showed that the conventional interest rate significantly affects Islamic bank financing in Malaysia, which indicates that Islamic bank financing is complementary to-rather than a substitute for-conventional bank financing. Another study by Karim et al. (2017) examined the roles of macroeconomic variables, namely the industrial production index (IPI) and the rate of financing (RoF), in Islamic bank financing, and their results showed no indication of either long-run or short-run asymmetric effects from the industrial production index and rate of financing on Islamic bank financing. Nursyamsiah (2017) found similar results regarding the relationship with Islamic banking financing with the real output, price level, interest rate, and trade. 
Given the limitations of the previous study, this study investigates the roles of the consumer price index, industrial production, interest rate, real exchange rate of Indonesian rupiah to the United States (US) dollar, and the Jakarta Islamic Index, which is the measurement of the effect of the Shariah stock market in Indonesia on Islamic bank deposits and financing. It is important to measure not only deposits but also the financing to obtain clear ideas about the Indonesia Islamic banking industry.

\section{Methodology}

\subsection{Unit Root Test}

The assumption that all the data series involved are stationary is required to test the cointegration between energy commodities and the stock market. To test the stationary of each data series, we used the test (Dickey and Fuller 1981) statistic using a generalized least squares (DF-GLS) by (Elliot et al. 1996). Thus, the modified test (denoted by DF-GLS $(\pi)$ in the tables and figure) was used as the $t$ statistic for testing $a_{0}=0$ in the regression:

$$
\Delta y_{t}^{d}=a_{0} \Delta y_{t-1}^{d}+a_{1} \Delta y_{t-1}^{d}+\cdots+a_{\mathrm{p}} \Delta y_{t-p}^{d}+\text { error. }
$$

When $d_{t}=\beta_{0}$, the estimate $\bar{\beta}_{0}$ is stochastically bounded and $T^{-\frac{1}{2}}\left(y_{[s T]}-\bar{\beta}_{0} \Rightarrow \omega W_{c}(s)\right.$; the $t$-statistic calculated from the demeaned data has the limiting representation $0.5\left(-W_{C}^{2}\right)^{-1 / 2}\left[W_{C}^{2}(1)=1\right]$, which is identical to that of $\hat{\tau}$. The critical values and asymptotic power are those of the conventional Dickey-Fuller $t$-statistic when there is no intercept.

To consider the possible shift regime in the unit root tests, we applied the Zivot and Andrews (1992) test (denoted by ZA in the tables and figure) to allow an endogenous structural break. Zivot and Andrews (1992) proposed a testing procedure where the timing of the break is estimated rather than assumed to be exogenous. The null hypothesis is that the variable under investigation that contains a unit root with a drift that excludes any structural break, while the alternative hypothesis is that the series is a trend stationery process with a one-time break occurring at an unknown point in time. In this methodology, $T_{\mathrm{b}}$ (the time of break) is chosen to minimize the one-sided $t$-statistics of $\alpha=1$.

The Zivot and Andrews (1992) model endogenizes a single structural break in a series (such as $y_{t}$ ) as follows:

$$
\begin{gathered}
H_{0}: y_{t}=\mu+y_{t-1}+e_{t} \\
H_{I} y_{t}=\hat{\mu}+\hat{\theta} D U_{t}\left(\hat{T}_{\mathrm{b}}\right)+\hat{\beta}_{t}+\hat{\gamma} D T_{t}\left(\hat{T}_{\mathrm{b}}\right)+\hat{a} y_{t-1}+\sum_{j=1}^{k} \hat{c}_{i} \Delta y_{t-j}+\hat{e}_{t} .
\end{gathered}
$$

As shown, this model accommodates the possibility of a change in the intercept as well as a broken trend. $D U_{t}$ is a sustained dummy variable that captures shifts in the intercept, and $D T_{t}$ is another dummy variable that represents a break in the trend occurring at time $T_{\mathrm{b}}$ where $D U_{t}=1$ if $t>$ $T_{\mathrm{b}}$ and zero otherwise, and $D T_{t}$ is equal to $\left(t-T_{\mathrm{b}}\right)$ if $\left(t>T_{\mathrm{b}}\right)$ and zero otherwise. The null hypothesis is rejected if the $\alpha$ coefficient is statistically significant.

\subsection{Gregory and Hansen Cointegration Test}

Conventional cointegration tests such as the Johansen-Juselius maximum likelihood (Johansen 1988,1991 ) and autoregressive distributed lag (ARDL) bounds test developed by Pesaran and Shin (1998) and Pesaran et al. (2001) do not contain structural breaks, which means that the cointegrating relationship remains unchanged over the period of time. This presumption is often violated due to structural breaks caused by economic crises, technological shocks, external shocks, or policy changes in time-series data (Ghost and Kanjilal 2016). Thus, the Gregory and Hansen test (Gregory and Hansen 1996) is used to test for cointegration between variables in the models with structural breaks. 
The GH test is based on structural changes and is a generalization of the usual residual-based cointegration test for the null of no cointegration, which considers three alternative models: the level shift $(\mathrm{C})$, level shift with trend $(\mathrm{C} / \mathrm{T})$, and the regime shift $(\mathrm{C} / \mathrm{S})$.

- $\quad$ Level shift (C) model:

$$
y_{1 t}=\mu_{1}+\mu_{2} \varphi_{2 \tau}+\alpha^{\mathrm{T}} y_{2 t}+e_{t}, \quad t=1, \ldots, n .
$$

In this parameterization, $\mu_{1}$ represents the intercept before the shift, and $\mu_{2}$ represents the change in the intercept at the time of the shift. We can also introduce the time trend into the level shift model.

- $\quad$ Level shift with trend $(\mathrm{C} / \mathrm{T})$ model:

$$
y_{1 t}=\mu_{1}+\mu_{2} \varphi_{2 \tau}+\beta_{\tau}+\alpha^{\mathrm{T}} y_{2 t}+e_{t}, \quad t=1, \ldots, n .
$$

Another possible structural change allows the slope vector to shift as well. This permits the equilibrium relation to rotate as well as shift parallel. We call this the regime shift model.

- $\quad$ Regime shift (C/S) model:

$$
y_{1 t}=\mu_{1}+\mu_{2} \varphi_{t \tau}+\beta_{\tau}+\alpha_{1}^{\mathrm{T}}+\alpha^{\mathrm{T}} y_{2 t} \varphi_{t \tau}+e_{t}, \quad t=1, \ldots, n .
$$

In this case, $\mu_{1}$ and $\mu_{2}$ are as in the level shift model, $\alpha_{1}$ denotes the cointegrating slope coefficients before the regime shift, and $\alpha_{2}$ denotes the change in the slope coefficients.

GH also modified the version of the cointegration augmented Dickey-Fuller (ADF) test of Engle and Granger (1987), and the $Z_{\alpha}$ and $Z_{t}$ tests of Phillips and Oualiaris (1990). Taking the unknown date of the change into account, the alternative versions of tests calculate the values of $\mathrm{ADF}^{*}, Z_{\alpha}{ }^{*}$, and $Z_{t}{ }^{*}$. These test statistics are now standard tools for the analysis of cointegrating regressions without regime shifts. However, our statistics of interest are the smallest values of the above statistics across all values of $\tau \in T$. We examined the smallest values, since small values of the test statistics constitute evidence against the null hypothesis. These test statistics are:

$$
\begin{gathered}
Z_{\alpha}^{*}=\inf _{\tau \in T} Z_{\alpha}(\tau), \\
Z_{\mathrm{t}}^{*}=\inf _{\tau \in T} Z_{\mathrm{t}}(\tau), \\
\mathrm{ADF}^{*}=\inf _{\tau \in T} \operatorname{ADF}(\tau) .
\end{gathered}
$$

\subsection{VECM, Granger Causality Test, and Impulse Response Function}

Cointegration would determine the model types of vector autoregression (VAR) or vector error correction mode (VECM), which we may then use to tell the direction of causality between each variable. If the variables are stationary and not cointegrated, the VAR model must be used. Therefore, VECM must be conducted if there is existing cointegration between the variables. The VECM formulation can be written as:

$$
\Delta y_{t}=\beta_{0}+\sum_{i=1}^{p-1} \Gamma_{i} y_{t}-1+\Pi y_{t-1}+B X_{t-1}+u_{t} .
$$

The $\Pi y_{t-1}$ is the error correction term, and the $k x r$ matrix $\Pi$ shows how the system reacts to deviations from the long-run equilibrium. The short-run dynamics are ruled by $\Gamma_{i}$. When $r$ is zero, then a process involving differences is appropriate, and when $r=k$, then a process with levels is appropriate. For $0<r<k$, an ECM exists that pushes back deviations from the long-run equilibrium. 
In the context of the VECM estimation, pairwise Granger causality tests and impulse response function analysis can be used for economic policy evaluation. The Granger causality test is a statistical hypothesis test for determining whether one time series is useful for forecasting another (Granger 1969). The Granger causality test can only be applied to pairs of variables and may produce misleading results when the true relationship involves three or more variables. (Granger 1969) stated that the concept of causality does not imply a cause-effect relationship, but rather is based only on the "predictability" or "forecast" ability. The complete story about the interaction between the variables of the system may not be completely revealed by the Granger causality. Indeed, it is interesting to know the response of one variable to an impulse in another variable in a system that involves a number of further variables as well. An impulse response indicates the reaction of any dynamic system in response to some external changes.

\section{Data and Results}

Aligning to the previous studies (Solarin et al. 2018, Haron and Azmi 2008; Adebola et al. 2011; Karim et al. 2017; Nursyamsiah 2017) that investigated the effects of the Islamic bank profit rate, industrial production index, real interest rates, Sharia index, exchange rate, trade, price level, and real output in Islamic banks, we determined the Islamic bank deposit and financing rates by following factors:

$$
\begin{aligned}
& \mathrm{DEP}_{\mathrm{t}}=f\left(\mathrm{CPI}_{\mathrm{t}}, \mathrm{IP}_{\mathrm{t}}, \mathrm{IR}_{\mathrm{t}}, \mathrm{ER}_{\mathrm{t}}, \mathrm{JII}_{\mathrm{t}}\right) \\
& \mathrm{FIN}_{\mathrm{t}}=f\left(\mathrm{CPI}_{\mathrm{t}}, \mathrm{IP}_{\mathrm{t}}, \mathrm{IR}_{\mathrm{t}}, \mathrm{ER}_{\mathrm{t}}, \mathrm{JII}_{\mathrm{t}}\right)
\end{aligned}
$$

where $\mathrm{DEP}_{\mathrm{t}}$ is the total Islamic bank deposit, and $\mathrm{FIN}_{\mathrm{t}}$ is the total Islamic bank financing. Both of these data were taken from monthly Islamic bank statistics published by Bank Indonesia and Otoritas Jasa Keuangan. CPI is the consumer price index, $\mathrm{IP}_{t}$ is industrial production, $\mathrm{IR}_{\mathrm{t}}$ is the interest rate released by Bank Indonesia, and $\mathrm{ER}_{\mathrm{t}}$ is the real exchange rate of Indonesian rupiah to the United States (US) dollar. All of this macroeconomic data is taken from the International Monetary Fund database. $\mathrm{JII}_{\mathrm{t}}$ is the Jakarta Islamic Index, which is the measurement of the Shariah stock market, and was taken from the Yahoo finance website. All the data are in logarithmic form and extend from January 2004 to June 2018.

Table 1 provides the descriptive statistics for the variables. The mean deposit value is 7.83 , and the standard deviation is 0.51 with a minimum of 6.82 and a maximum of 8.53 . With respect to financing, the mean value is 7.82 , the standard deviation is 0.49 , the minimum is 6.76 , and the maximum is 8.47. The two variables of deposit and financing were found to be the most volatile variables: almost two to five times higher in volatility than the others. Therefore, the mean values of CPI, IP, ER, IR, and JII are 2.01, 2.03, 4.02, 0.85, and 2.63, with standard deviations of $0.111,0.073,0.072,0.110$, and 0.231 , respectively.

Table 1. Summary statistics of the variables.

\begin{tabular}{cccccccc}
\hline Variables & Deposit & Financing & CPI & IP & ER & IR & JII \\
\hline Mean & 7.83 & 7.82 & 2.01 & 2.03 & 4.02 & 0.85 & 2.63 \\
Standard Error & 0.04 & 0.04 & 0.01 & 0.01 & 0.01 & 0.01 & 0.02 \\
Median & 7.90 & 7.87 & 2.02 & 2.01 & 3.98 & 0.87 & 2.72 \\
Standard Deviation & 0.51 & 0.49 & 0.11 & 0.07 & 0.07 & 0.11 & 0.23 \\
Sample Variance & 0.26 & 0.24 & 0.01 & 0.01 & 0.01 & 0.01 & 0.05 \\
Kurtosis & -1.27 & -1.20 & -0.88 & -0.93 & -1.29 & 0.23 & -0.40 \\
Skewness & -0.30 & -0.35 & -0.39 & 0.31 & 0.58 & 0.150 & -0.91 \\
Range & 1.71 & 1.71 & 0.38 & 0.30 & 0.24 & 0.48 & 0.81 \\
Minimum & 6.82 & 6.76 & 1.78 & 1.90 & 3.93 & 0.63 & 2.08 \\
Maximum & 8.53 & 8.47 & 2.20 & 2.20 & 4.17 & 1.11 & 2.90 \\
\hline
\end{tabular}

Note: all variable are in logarithm. CPI: consumer price index; IP: industrial production; ER: real exchange rate of Indonesian rupiah to the United States dollar; IR: interest rate released by Bank Indonesia; JII: Jakarta Islamic Index. 
To test cointegration, the assumption that all data series involved are stationary is required. To test the stationarity of each data series, we used DF-GLS (Elliot et al. 1996), and to consider the possible shift regime in the unit root tests, we applied the Zivot and Andrews (1992) test to allow an endogenous structural break. Table 2 points out the results of the unit root test with intercepts and trends. The results indicate that all variables with different data frequencies follow I(1) processes with a $5 \%$ level of significance. Finally, the structural break, as identified by the Zivot-Andrews test, varies by time and estimated model, although most of them appear in 2008 and 2009. In these years, the world economy suffered from a financial crisis that led to significant economic failure worldwide. Evidence found by Erfani and Vasigh (2018) shows that Islamic bank equity-based financing provides a buffer to Islamic banking during the financial crisis. Since a key principle of Islamic banking is profit-sharing and loss-bearing banking, each party in a transaction must share the risks and rewards associated with the transaction. Thus, not only do the banks suffer from the crisis, but there is risk sharing from the bank to their stakeholders and customers.

Table 2. The results of the unit root test.

\begin{tabular}{|c|c|c|c|c|c|}
\hline \multirow{2}{*}{$\begin{array}{c}\text { Unit Root } \\
\text { Test }\end{array}$} & \multicolumn{3}{|c|}{ ZA } & \multicolumn{2}{|c|}{ DF-GLS } \\
\hline & $A$ & $B$ & $C$ & Without Trend & With Trend \\
\hline \multicolumn{6}{|c|}{ Levels } \\
\hline Deposit & $\begin{array}{c}-3.56 \\
(2009 \mathrm{M} 07)\end{array}$ & $\begin{array}{c}-4.64 \\
(2013 \mathrm{M} 04)\end{array}$ & $\begin{array}{c}-4.49 \\
(2011 \mathrm{M} 09)\end{array}$ & $\begin{array}{c}4.21 \\
0\end{array}$ & $\begin{array}{c}-0.32 \\
1\end{array}$ \\
\hline Financing & $\begin{array}{c}-2.70 \\
(2014 \mathrm{M} 07)\end{array}$ & $\begin{array}{c}-4.97 \\
(2013 \mathrm{M} 06)\end{array}$ & $\begin{array}{c}-6.07 \\
(2012 \mathrm{M} 04)\end{array}$ & $\begin{array}{c}1.42 \\
3\end{array}$ & $\begin{array}{c}-0.63 \\
3\end{array}$ \\
\hline CPI & $\begin{array}{c}-2.42 \\
(2015 \mathrm{M} 01)\end{array}$ & $\begin{array}{c}-2.67 \\
(2009 \mathrm{M} 07)\end{array}$ & $\begin{array}{c}-3.28 \\
(2007 \mathrm{M} 12)\end{array}$ & $\begin{array}{c}3.13 \\
1\end{array}$ & $\begin{array}{c}-0.84 \\
1\end{array}$ \\
\hline IP & $\begin{array}{c}-4.68 \\
(2009 \mathrm{M} 07)\end{array}$ & $\begin{array}{c}-3.82 \\
(2009 \mathrm{M} 07)\end{array}$ & $\begin{array}{c}-4.75 \\
(2009 \mathrm{M} 07)\end{array}$ & $\begin{array}{c}3.26 \\
12\end{array}$ & $\begin{array}{c}-3.40 \\
1\end{array}$ \\
\hline IR & $\begin{array}{c}-4.06 \\
(2013 \mathrm{M} 07)\end{array}$ & $\begin{array}{c}-3.44 \\
(2011 \mathrm{M} 04)\end{array}$ & $\begin{array}{c}-4.15 \\
(2013 \mathrm{M} 07)\end{array}$ & $\begin{array}{c}-1.64 \\
1\end{array}$ & $\begin{array}{c}-2.32 \\
1\end{array}$ \\
\hline ER & $\begin{array}{c}-3.97 \\
(2013 \mathrm{M} 07)\end{array}$ & $\begin{array}{c}-3.46 \\
(2011 \mathrm{M} 04)\end{array}$ & $\begin{array}{c}-4.13 \\
(2013 \mathrm{M} 07)\end{array}$ & $\begin{array}{c}0.51 \\
0\end{array}$ & $\begin{array}{c}-1.75 \\
0\end{array}$ \\
\hline JII & $\begin{array}{c}-3.72 \\
(2006 \mathrm{M} 07)\end{array}$ & $\begin{array}{c}-3.93 \\
(2007 \mathrm{M} 05)\end{array}$ & $\begin{array}{c}-4.17 \\
(2008 \mathrm{M} 03)\end{array}$ & $\begin{array}{c}0.23 \\
1\end{array}$ & $\begin{array}{c}-1.61 \\
1\end{array}$ \\
\hline \multicolumn{6}{|c|}{ First Difference } \\
\hline Deposit & $\begin{array}{l}-14.91^{* * *} \\
(2009 \mathrm{M} 07)\end{array}$ & $\begin{array}{l}-14.90^{* * *} \\
(2009 \mathrm{M} 07)\end{array}$ & $\begin{array}{l}-14.97^{* * *} \\
(2009 \mathrm{M} 07)\end{array}$ & $\begin{array}{c}-20.72^{* * *} \\
0\end{array}$ & $\begin{array}{c}-21.44^{* * *} \\
0\end{array}$ \\
\hline Financing & $\begin{array}{c}-6.13^{* * *} \\
(2013 \mathrm{M} 06)\end{array}$ & $\begin{array}{c}-5.52 * * * \\
(2011 \mathrm{M} 11)\end{array}$ & $\begin{array}{c}-6.13^{* * *} \\
(2013 \mathrm{M} 06)\end{array}$ & $\begin{array}{c}-2.54^{* *} \\
2\end{array}$ & $\begin{array}{c}-3.34^{* * *} \\
2\end{array}$ \\
\hline CPI & $\begin{array}{c}-9.4^{* * *} \\
(2008 \mathrm{M} 10)\end{array}$ & $\begin{array}{c}-9.65^{* * *} \\
(2009 \mathrm{M} 07)\end{array}$ & $\begin{array}{c}-9.74 * * * \\
(2009 \mathrm{M} 07)\end{array}$ & $\begin{array}{c}-8.56^{* * *} \\
0\end{array}$ & $\begin{array}{c}-9.58^{* * *} \\
0\end{array}$ \\
\hline IP & $\begin{array}{l}-13.03^{* * *} \\
(2007 \mathrm{M} 10)\end{array}$ & $\begin{array}{l}-13.05^{* * *} \\
(2016 \mathrm{M} 03)\end{array}$ & $\begin{array}{l}-13.04^{* * *} \\
(2007 \mathrm{M} 10)\end{array}$ & $\begin{array}{c}-2.15^{*} \\
11\end{array}$ & $\begin{array}{c}-3.29 * \\
11\end{array}$ \\
\hline IR & $\begin{array}{c}-5.02 * * * \\
(2016 \mathrm{M} 01)\end{array}$ & $\begin{array}{c}-4.87^{* * *} \\
(2007 \mathrm{M} 01)\end{array}$ & $\begin{array}{c}-5.25^{* * *} \\
(2016 \mathrm{M} 01)\end{array}$ & $\begin{array}{c}-5.90^{* * *} \\
0\end{array}$ & $\begin{array}{c}-5.85^{* * *} \\
0\end{array}$ \\
\hline ER & $\begin{array}{c}-7.17^{* * *} \\
(2009 \mathrm{M} 03)\end{array}$ & $\begin{array}{c}-7.02 * * * \\
(2009 \mathrm{M} 07)\end{array}$ & $\begin{array}{c}-7.16^{* * *} \\
(2009 \mathrm{M} 03)\end{array}$ & $\begin{array}{c}-11.91^{* * *} \\
0\end{array}$ & $\begin{array}{c}-11.83^{* * *} \\
0\end{array}$ \\
\hline JII & $\begin{array}{l}-10.87^{* * *} \\
(2008 \mathrm{M} 12)\end{array}$ & $\begin{array}{l}-10.47^{* * *} \\
(2008 \mathrm{M} 09)\end{array}$ & $\begin{array}{l}-11.12 * * * \\
(2008 \mathrm{M} 11)\end{array}$ & $\begin{array}{c}-10.38^{* * *} \\
0\end{array}$ & $\begin{array}{c}-10.51 * * * \\
0\end{array}$ \\
\hline
\end{tabular}

Notes: ${ }^{*}, * *, * * *$ indicate significance at the $10 \%, 5 \%$, and $1 \%$ levels, respectively. The Dickey-Fuller test statistic using a generalized least squares (DF-GLS) and ZA test are the unit root tests proposed by Elliot et al. (1996) and Zivot and Andrews (1992), respectively. The numbers in parentheses are the lag order, which was selected on the basis of the Schwarz Criterion (SC), in the DF-GLS tests. The numbers in the brackets of the ZA tests are the estimated structural break dates. 
The GH test is based on structural changes and is a generalization of the usual residual-based cointegration test for the null of no cointegration. The level shift (C), level shift with trend (C/T), and regime shift $(\mathrm{C} / \mathrm{S})$ models are the three alternative models for the $\mathrm{GH}$ test. It also modifies the version of the cointegration ADF test of Engle and Granger (1987) and the $Z_{\alpha}$ and $Z_{t}$ tests of Phillips and Oualiaris (1990). Taking the unknown date of the change into account, the alternative versions of tests can be used to calculate the values of $A D F^{*}, Z_{\alpha}{ }^{*}$, and $Z_{t}{ }^{*}$.

The results of the GH tests are reported in Table 3; these tests are based on a single equation with Islamic bank deposits and Islamic bank financing as the dependent variables. The test rejected the null hypothesis of no cointegration at a level of significance of $1 \%$ for the entire sample of modified $A D F^{*}, Z_{\alpha}{ }^{*}$, and $Z_{t}^{*}$ values. It also disclosed the existence of a long-run cointegrating relationship with structural breaks in both deposit and financing cases for the consumer price index, industrial production, interest rate, exchange rate, and Jakarta Islamic Index. There are also different pieces of empirical evidence revealed for a relationship between Islamic bank deposits and financing. In the deposit case, most of the structural breaks appeared in January 2006. Therefore, April 2007 emerged as the biggest structural break for financing.

Table 3. The Results of the Gregory and Hansen Cointegration Test.

\begin{tabular}{|c|c|c|c|}
\hline Test Statistic & Level Shift & Level Shift with Trend & Regime Shift \\
\hline \multicolumn{4}{|c|}{ Deposit } \\
\hline$A D F^{*}$ & $\begin{array}{l}-14.69 * * * \\
(2012 \mathrm{M} 01)\end{array}$ & $\begin{array}{l}-14.66^{* * * *} \\
(2006 \mathrm{M} 01)\end{array}$ & $\begin{array}{l}-15.18^{* * *} \\
(2006 \mathrm{M} 01)\end{array}$ \\
\hline$Z_{\alpha}{ }^{*}$ & $\begin{array}{l}-243.2 * * * \\
(2011 \mathrm{M} 12)\end{array}$ & $\begin{array}{l}-243.7^{* * *} \\
(2009 \mathrm{M} 01)\end{array}$ & $\begin{array}{l}-242.8^{* * *} \\
(2014 \mathrm{M} 12)\end{array}$ \\
\hline$Z_{t}^{*}$ & $\begin{array}{l}-22.94^{* * *} \\
(2011 \mathrm{M} 12)\end{array}$ & $\begin{array}{l}-22.91 * * * \\
(2006 \mathrm{M} 01)\end{array}$ & $\begin{array}{l}-22.91^{* * *} \\
(2012 \mathrm{M} 01)\end{array}$ \\
\hline \multicolumn{4}{|c|}{ Financing } \\
\hline$A D F^{*}$ & $\begin{array}{l}-16.031^{* * *} \\
(2007 \mathrm{M} 11)\end{array}$ & $\begin{array}{l}-16.82^{* * *} \\
(2007 \mathrm{M} 05)\end{array}$ & $\begin{array}{l}-18.17^{* * * *} \\
(2007 \mathrm{M} 04)\end{array}$ \\
\hline$Z_{\alpha}{ }^{*}$ & $\begin{array}{l}-210.9^{* * *} \\
(2013 \mathrm{M} 10)\end{array}$ & $\begin{array}{l}-211.8^{* * *} \\
(2007 \mathrm{M} 04)\end{array}$ & $\begin{array}{l}-221.0^{* * *} \\
(2007 \mathrm{M} 04)\end{array}$ \\
\hline$Z_{t}^{*}$ & $\begin{array}{l}-16.52 * * * \\
(2013 \mathrm{M} 10)\end{array}$ & $\begin{array}{l}-16.84^{* * *} \\
(2007 \mathrm{M} 04)\end{array}$ & $\begin{array}{l}-18.23^{* * *} \\
(2007 \mathrm{M} 04)\end{array}$ \\
\hline
\end{tabular}

Notes: $\mathrm{ADF}^{*}, Z_{\alpha}{ }^{*}$, and $Z_{\mathrm{t}}{ }^{*}$ are modifies the version of cointegration augmented Dickey-Fuller (ADF) test of Engle and Granger (1987) and the $Z_{\alpha}$ and $Z_{t}$ tests of Phillips and Oualiaris (1990), respectively. The critical values are from Gregory and Hansen (1996). ${ }^{* * *}$ indicates significance at the $1 \%$ level. The numbers in brackets are estimated structural break dates.

In this period of time, the global financial crisis started, which weakened the global economy and finance. People started to hold onto their money rather than depositing it. A bank rush also occurred, since people were afraid that bank liquidity would mean that they would not get their savings back. Liquidity and debt default risk increased in the crisis period, causing banks to retain their liquidity instead of delivering finances to the customers. The non-performing financing doubled from 2005 to 2007, accounting for $2.35 \%$ to $6.63 \%$ in August 2007.

Since cointegration only reveals the nature of the long-term effect of time-series data, additional analysis was needed to measure how each macroeconomic variable influences Islamic bank deposits and financing. Thus, we applied the Granger causality test and impulse response function to the model.

\subsection{The Results of VECM and the Granger Causality Test}

As our results in Table 3 suggest existing cointegration with structural breaks, we further conducted VECM to determine the causality and evaluate the short-term properties of the variables. 
The cointegration rank of VECM indicates the number of cointegration vectors, while the negative and significant coefficient of the ECM shows that any short-term shocks between the independent variables will give rise to a stable long-term relationship. The results of the VECM tests for deposit and financing estimations are shown in Table 4.

Table 4. The vector error correction mode (VECM) result of deposit and financing estimation.

\begin{tabular}{|c|c|c|c|c|}
\hline $\begin{array}{l}\text { Dependent } \\
\text { Variable }\end{array}$ & $\begin{array}{c}\text { Independent } \\
\text { Variable }\end{array}$ & Coefficient & $T$-Statistic Value/ $p$-Value & $F$-Statistics $/ p$-Value \\
\hline \multirow{6}{*}{$\Delta$ Deposit } & $\Delta \mathrm{CPI}(-1)$ & -0.55 & $1.08(0.47)$ * & \multirow{6}{*}{$10.61(0.00)^{* * *}$} \\
\hline & $\Delta \mathrm{IP}(-1)$ & -0.52 & $-4.66(0.02)^{* *}$ & \\
\hline & $\Delta \mathrm{ER}(-1)$ & 0.29 & $1.75(0.04)^{* *}$ & \\
\hline & $\Delta \operatorname{IR}(-1)$ & -0.15 & $-1.25(0.09) *$ & \\
\hline & $\Delta \mathrm{JII}(-1)$ & 0.15 & $2.13(0.03)^{* *}$ & \\
\hline & $\mathrm{ECT}(-1)$ & -0.04 & $-3.90(0.00)^{* * *}$ & \\
\hline \multirow{6}{*}{$\Delta$ Financing } & $\Delta \mathrm{CPI}(-1)$ & -0.67 & $-3.14(0.07) *$ & \multirow{6}{*}{$12.05(0.00)^{* * *}$} \\
\hline & $\Delta \mathrm{IP}$ & -0.12 & $-2.97(0.01) * *$ & \\
\hline & $\Delta \mathrm{ER}$ & 0.06 & $0.93(0.07) *$ & \\
\hline & $\Delta \mathrm{IR}$ & -0.01 & $-0.31(0.16)$ & \\
\hline & $\Delta \mathrm{JII}$ & -0.01 & $-0.37(0.08) *$ & \\
\hline & $\mathrm{ECT}(-1)$ & -0.01 & $-8.26(0.00)^{* * *}$ & \\
\hline
\end{tabular}

Note: ${ }^{* * *}, * *$, and $*$ indicate significance at the $1 \%, 5 \%$, and $10 \%$ levels; the $P$-values are shown in parentheses.

The error correction term in the estimation is negative and statistically significant for all the variables (see Table 4). This indicates long-term Granger causality both from deposits and financing to the consumer price index, industrial production, exchange rate, interest rate, and Jakarta Islamic Index. The negative coefficient of $\mathrm{ECT}_{t-1}$ from deposits and financing are 0.04 and 0.01 . This indicates that previous disequilibrium in the deposit system will be corrected monthly at a speed of $4 \%$, while the monthly speed adjustment of financing is $1 \%$. These results reveal that deposits will reach a long-term equilibrium steady-state position faster than financing when there are deviations in the system.

To see the predictability of the variable on the others, we conducted the pairwise Granger causality test. The Granger causality test is a statistical hypothesis test that determines whether one time series is useful for forecasting another (Granger 1969). The Granger causality test can be applied only to pairs of variables and may produce misleading results when the true relationship involves three or more variables. (Granger 1969) stated that the concept of causality does not imply a cause-effect relationship, but rather, is based only on "predictability" or "forecast" ability.

The results of Table 5 show that there is bidirectional causality between deposits and industrial production, showing that industrial production will increase when there is an increase in bank deposits and vice versa. There are correlation cycles between deposits and industrial production. A rise in banking deposits increases the availability of commercial lending for industrial support. It helps the industry accelerate business and gain more profits, and results in higher industrial production. On the other hand, higher industrial production is reflected in a busting market condition and causes the growth of bank deposits. People will save more on bank deposits, since they obtain a higher return from their business. These results can also be explained by the intermediary function of the bank. Due to the intermediary function between lenders and borrowers, banks have an important role for all economies. Not only can investors reach the money they need for their business activities, but consumers are also able to spend their future incomes (Yuksel et al. 2018).

The results in Table 5 show no causality between the CPI and deposits. A change in inflation would not have any impact on Islamic banks, as depositors do not see the time-related value of money. Islam culture does not view money as a commodity; rather, it is used as a medium of exchange and value storage. Therefore, it cannot be sold at a price higher than its face value or rented out (Nurrachmi et al. 2012). People deposit their money into Islamic banks for future expenditure, such as children's 
school costs, health care, travel, and pilgrimage, which is a journey of worship involving a visit to Ka'bah and its surroundings in the city of Mecca to perform various Islamic rituals.

Table 5. Deposit pairwise granger causality tests.

\begin{tabular}{|c|c|c|c|c|}
\hline Null Hypothesis: & F-Statistic & Prob. & Granger Cause & Direction \\
\hline CPI does not Granger Cause Deposit & 0.53 & $0.78^{* * *}$ & $\mathrm{NO}$ & \multirow{2}{*}{ None } \\
\hline Deposit does not Granger Cause CPI & 1.88 & 0.08 & $\mathrm{NO}$ & \\
\hline IP does not Granger Cause Deposit & 2.21 & $0.01 * *$ & YES & \multirow{2}{*}{ Bidirectional } \\
\hline Deposit does not Granger Cause IP & 1.37 & $0.05^{*}$ & YES & \\
\hline IR does not Granger Cause Deposit & 1.71 & 0.12 & $\mathrm{NO}$ & \multirow{2}{*}{ None } \\
\hline Deposit does not Granger Cause IR & 1.24 & 0.29 & $\mathrm{NO}$ & \\
\hline ER does not Granger Cause Deposit & 2.42 & $0.03 * *$ & YES & \multirow{2}{*}{ Unidirectional } \\
\hline Deposit does not Granger Cause ER & 1.78 & 0.11 & $\mathrm{NO}$ & \\
\hline JII does not Granger Cause Deposit & 2.19 & $0.05^{* *}$ & YES & \multirow{2}{*}{ Unidirectional } \\
\hline Deposit does not Granger Cause JII & 1.50 & 0.18 & $\mathrm{NO}$ & \\
\hline
\end{tabular}

Note: ${ }^{* *}, * *$, and ${ }^{*}$ indicate significance at the $1 \%, 5 \%$, and $10 \%$ levels, respectively.

Our results suggest that there is no causality between the interest rate and deposit. It is clearly stated that Islamic banking does not allow an interest rate to be paid and received from banking activity. The power of faith is the reason behind the abandonment of the interest rate. Mushtaq and Siddiqui (2017) discovered that most of the depositors in Islamic banking do not really care about increases and decreases in the interest rate. Islamic bank depositors will keep depositing their money as they believe in Islamic law. This result is also supported Tariq and Masih (2016), Kassim et al. (2009), Sukmana and Kassim (2010), Hassan (2016), who found that the interest rate does not have any significant effect on Islamic bank deposits.

The exchange rate and the Jakarta Islamic Index will affect deposit changes in the short term. Exchange rate appreciation will increase bank deposits. As the economy becomes more competitive and productive, exporters and importers gain more returns from their businesses, and they will deposit more money into banks. In addition, the stock market is mostly seen as the macroeconomic and business parameters within the country. An increasing stock market index is seen as an indication of growth in economic conditions; thus, investors will receive high returns and increase their deposits in the bank. A composite stock index that leads to Islamic bank deposits was also identified by Solarin et al. (2018) and Haron and Azmi (2008).

Moving to Table 6, bidirectional causality is shown between CPI and financing, while the other variables show unidirectional causality. The effect of financing on purchasing items through the Murabahah scheme accounts for almost 70\% of Islamic bank financing in Indonesia. Customers purchasing large amounts of consumptive or productive goods means that Islamic banks rely on inflation within the country. Low inflation moves Islamic bank financing forward, giving banks the ability to purchase more goods, attract financial customers, and lower costs. Therefore, the purchase of more items and demands by Islamic banks will cause higher inflation, and these two variables impact each other.

Our results show that financing could cause industrial production in the short-run, in contrast to the results of Karim et al. (2017), who stated that industrial production does not cause Islamic bank financing in both the short-term and long-term. Our results show that financing could increase industry capital and thus the support needed to run businesses. Since industrial expansion could require lots of firm capital, most industries count on Islamic bank financing to support business expansion. 
Table 6. Financing Pairwise Granger Causality Tests.

\begin{tabular}{|c|c|c|c|c|}
\hline Null Hypothesis: & F-Statistic & Prob. & Granger Cause & Direction \\
\hline CPI does not Granger Cause FINANCING & 4.61 & $0.01^{* *}$ & Yes & \multirow{2}{*}{ Bidirectional } \\
\hline FINANCING does not Granger Cause CPI & 2.84 & $0.06^{*}$ & Yes & \\
\hline IP does not Granger Cause FINANCING & 0.18 & 0.83 & No & \multirow{2}{*}{ Unidirectional } \\
\hline FINANCING does not Granger Cause IP & 10.44 & $0.00 * * *$ & Yes & \\
\hline IR does not Granger Cause FINANCING & 10.64 & $0.00 * * *$ & Yes & \multirow{2}{*}{ Unidirectional } \\
\hline FINANCING does not Granger Cause IR & 1.54 & 0.22 & No & \\
\hline ER does not Granger Cause FINANCING & 6.25 & $0.00 * * *$ & Yes & \multirow{2}{*}{ Unidirectional } \\
\hline FINANCING does not Granger Cause ER & 1.44 & 0.24 & No & \\
\hline JII does not Granger Cause FINANCING & 1.34 & 0.26 & No & \multirow{2}{*}{ Unidirectional } \\
\hline FINANCING does not Granger Cause JII & 2.72 & $0.07 *$ & Yes & \\
\hline
\end{tabular}

$* * * * *$, and ${ }^{*}$ indicates significance at the $1 \%, 5 \%$, and $10 \%$ levels, respectively.

The results shown in Table 6 also reveal that the interest rate leads to financing in Islamic banks. It is interesting to note that Table 6 shows that the interest rate does not lead to changes in Islamic bank deposits. We found that the interest rate is considered to be one of the causes of changes in Islamic bank financing. The same finding was shown by Adebola et al. (2011). They revealed that the conventional interest rate significantly affects Islamic bank financing in Malaysia, which indicates that Islamic bank financing is complementary rather than a substitute for conventional bank financing. Before taking loans from the bank, business stakeholders will calculate all the costs and risks that occur from it. Indeed, they will compare the interest rates from conventional banks and marginal costs in Islamic banks and decide which can give them more benefit.

The exchange rate causes Islamic bank financing, and the effects of financing on the Islamic stock market are also indicated in Table 6. Developing countries do not expect Indonesia to be the home to "hot money" investment. Foreign capital investment is an important key to grow the economy and businesses in developing countries. Consequently, negative events such as a sudden decline in domestic currency or currency devaluation will result in foreign capital flight from the country. This will lead to hard times for businesses and cause debt defaults in financing.

Since Islamic banks and Islamic stocks are related to each other, the availability of financing for the Islamic industry will increase profits, returns, and the stock index. A rise in Islamic industry business will boost the Islamic composite stock index, and is a sign of good business and economic conditions within the country.

\subsection{The Result of Impulse Responses}

The complete story about the interactions between the variables of a system may not be completely revealed by Granger causality. Indeed, it is interesting to know the response of one variable to an impulse in another variable in a system that involves a number of other variables as well. An impulse response indicates the reaction of any dynamic system in response to some external changes. Figure 1 presents the impulse responses for all variables following changes of two standard deviations.

Islamic bank deposits respond positively to the shock of inflation, industrial production, interest rate, and JII. These positive responses are highly volatile in the first three periods for both inflation and industrial production variables. Deposits tend to show a calm reaction during the fluctuation of inflation; this result is in line with our Granger cause result. Therefore, a rise in industrial production will increase Islamic bank deposits, even though the first two periods of change show a negative response of Islamic bank deposits toward industrial production change. Changes in the Islamic stock index cause positive responses in Islamic bank deposits. Even though this positive response rises and falls throughout the fifth period, it stands to rise more over the rest of the time period. 

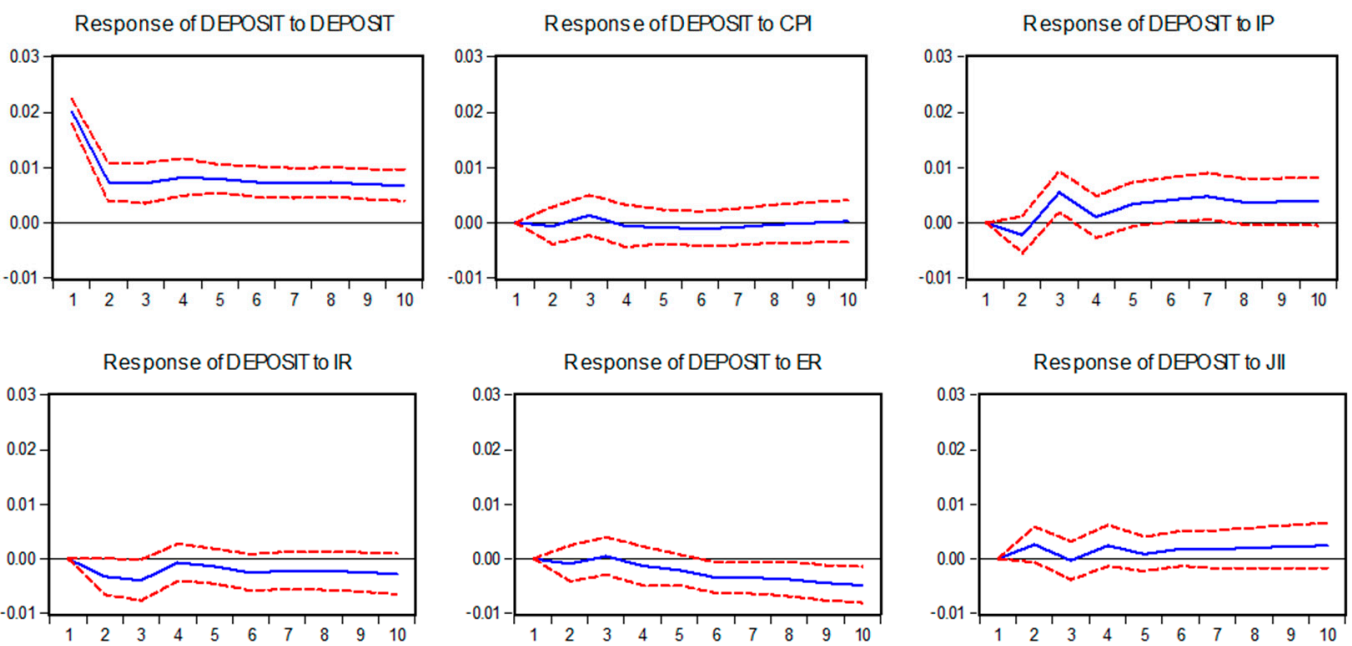

Figure 1. Response of deposits to macroeconomic shock.

Figure 1 also indicates a negative response of Islamic bank deposits toward the volatility of the interest rate and exchange rate. As interest rates are not allowed in Islamic bank activity, we found that changes in the interest rate cause negative changes in Islamic bank deposits at all times. In other words, a rise in the interest rate of conventional banks will decrease deposits in Islamic banks. Furthermore, exchange rate shock results in positive responses of deposits in the first quarter before turning to a negative response as volatility occurs. A sudden change in the exchange rate could hurt Islamic bank deposits, as it brings about unstable economic conditions and high inflation, and means that people have a lower ability to save in Islamic bank deposits.

Compared to deposits, which react in a similar manner to every type of shock, Figure 2 shows that financing has a dynamic response. Financing reacts negatively to consumer price index changes in all periods of time, supporting our Granger causality test (Table 6). An increase in inflation pushes Islamic banks to reduce financing, as the cost of financing is high, and few consumers can afford to do financing in unstable economic conditions. A decreasing response from positive to negative is revealed for the interest and exchange rates. This shows that in the short-term, shocks from the interest and exchange rates will have positive effects on financing before turning to negative effects for the sixth and third periods of the interest and exchange rates, respectively.
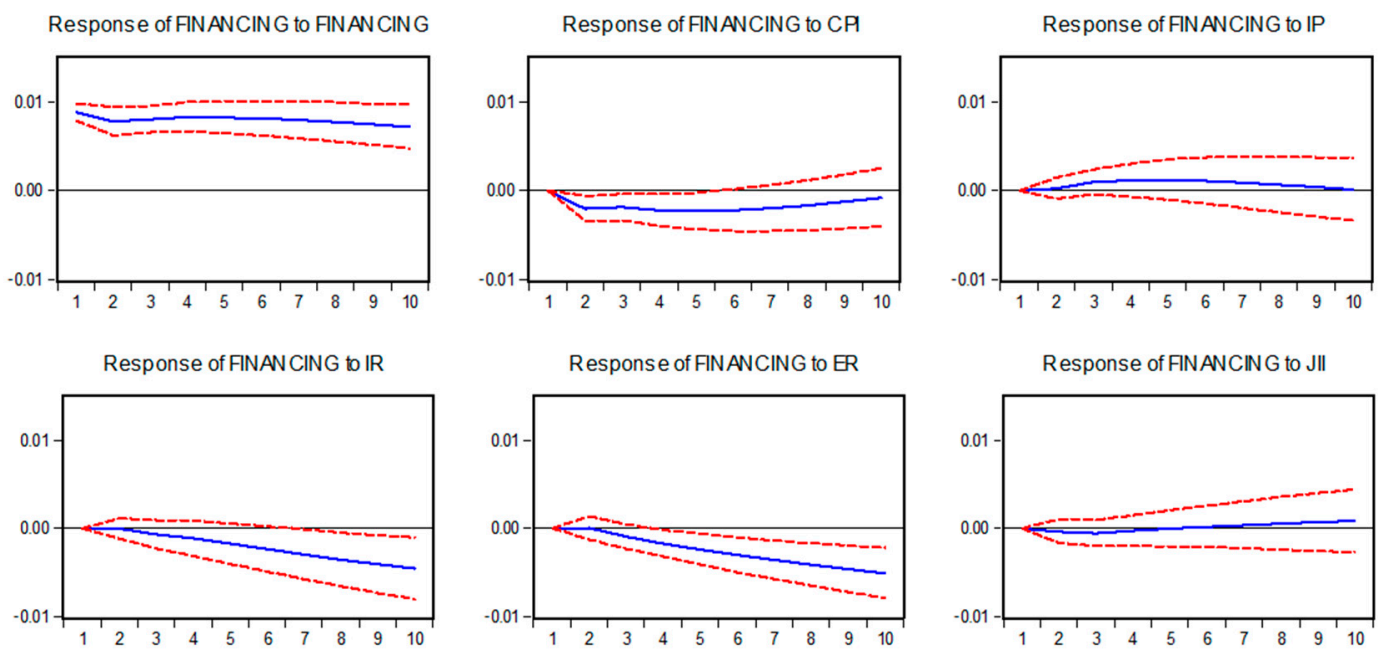

Figure 2. Response of financing to macroeconomic shock.

Financing shows a positive response to industrial production and changes in the Jakarta Islamic Index, where this response gets higher each time. Industrial production and the stock market index are 
widely seen as macroeconomic indicators that indicate the condition of the economy and business within the countries. Hence, increases in both of the indicators lead to growth in economic conditions, which then encourages Islamic banks to issue more financing as the risk of debt default decreases.

\section{Conclusions}

The purpose of this study was to investigate the factors that determine Islamic bank savings and financing in Indonesia. The results disclose the existence of a long-term co-integrating relationship with structural breaks in both deposit and financing cases for the consumer price index, industrial production, interest rate, exchange rate, and Jakarta Islamic Index. Most of the structural breaks appeared in January 2006 and April 2007 for deposit and financing, which was the first stage of the financial crisis. Further results from the VECM test suggest that any short-term shocks between deposit and financing will give rise to a stable long-term relationship.

The interest rate was found to have no effect on Islamic banking deposits, clearly outlining the differences between Islamic banks and conventional banks. As interest rates are prohibited, Islamic bank depositors are not affected by them, while depositors in conventional banks will be interested in the interest rate return on their deposits. Our results are in line with those of Tariq and Masih (2016), Kassim et al. (2009), Sukmana and Kassim (2010), and Hassan (2016). The exchange rate and stock price, as measures of the economic condition, were shown to have impacts on both deposit and financing in Islamic banks. Therefore, there is bidirectional causality between deposits and industrial production and the consumer price index on financing. This finding shows that real activity, as measured by industrial production, is a highly determinant factor of Islamic bank deposits, while inflation, as measured by the customer price index, is the determinant factor of Islamic bank financing.

From this research, we derived some recommendations for the government and stakeholders in Indonesian Islamic banking. The countries should look for incentives to boost industrial production and the real sector, thus giving Islamic banks more opportunities to carry out their intermediary function. Since consumption financing accounts for more in Islamic banking activity, an effective monetary policy on inflation should also be made by the government to stabilize the consumer market. This will contribute to the purchase and financing ability of consumers.

Our analysis was limited to Islamic banking in Indonesia as a whole, and only five macroeconomic indicators are covered in the model. Further research on disaggregate data on Islamic banking is needed to discover the macroeconomic effect on each of the Islamic bank entities. Other macroeconomic variables, GDP, money supply, economic growth, and trade could also be considered in different models.

Funding: The author received no specific funding for this work.

Acknowledgments: The author gratefully acknowledge the referees for their constructive comments and recommendation.

Conflicts of Interest: The author declares no conflict of interest.

\section{References}

Adebola, Solarin Sakiru, Wan Sulaiman Wan Yusoff, and Jauhari Dahalan. 2011. The impact of macroeconomic variables on Islamic Banks financing in Malaysia. Research Journal of Finance and Accounting 2: 22-32.

Akhtar, Muhammad Farhan, Khizer Ali, and Shama Sadaqat. 2011. Liquidity risk management: A comparative study between conventional and Islamic banks of Pakistan. Interdisciplinary Journal of Research in Business 1: 35-44.

Alwyni, Farouk A. 2011. Islamic Banking in Indonesia Growth and Performance Review. Available online: www.isfire.net (accessed on 23 April 2019).

Athukorala, Prema-Chandra, and Pang-Long Tsai. 2003. Determinants of household saving in Taiwan: Growth, demography and public policy. The Journal of Development Studies 39: 69-88. [CrossRef]

Bohachova, Olga. 2008. The Impact of Macroeconomic Factors on Risks in the Banking Sector: A Cross-Country Empirical Assessment. Tübingen: Institut für Angewandte Wirtschaftsforschung (IAW), p. 44. 
Chernykh, Lucy, and Alexandra K. Theodossiou. 2011. Determinants of bank long-term lending behavior: Evidence from Russia. Multinational Finance Journal 15: 193-216. [CrossRef]

Cowling, Marc, and Paul Westhead. 1996. Bank lending decisions and small firms: Does size matter? International Journal of Entrepreneurial Behavior \& Research 2: 52-68.

Dickey, David A., and Wayne A. Fuller. 1981. Likelihood ratio statistics for autoregressive time series with a unit root. Econometrica: Journal of the Econometric Society 49: 1057-72. [CrossRef]

Elliot, Graham, Thomas J. Rothenberg, and James H. Stock. 1996. Efficient tests for an autoregressive unit root. Econometrica 64: 813-36. [CrossRef]

Engle, Robert F., and C. W. J. Granger. 1987. Co-integration and error correction: Representation, estimation and testing. Econometrica: Journal of the Econometric Society 55: 251-76. [CrossRef]

Erfani, G. Rod, and Bijan Vasigh. 2018. The impact of the global financial crisis on profitability of the banking industry: A comparative analysis. Economies 6: 66. [CrossRef]

Eriemo, Nathanael O. 2014. Macroeconomic Determinants of bank deposits in Nigeria. Journal of Economic and Sustainable Development 5: 49-58.

Ghost, Sajal, and Kakali Kanjilal. 2016. Co-movement of international crude oil price and Indian stock market: Evidences from nonlinear cointegration tests. Energy Economics 53: 111-17.

Granger, C. W. J. 1969. Investigating causal relations by econometric models and cross-spectral methods. Econometrica: Journal of the Econometric Society 37: 24-36. [CrossRef]

Gregory, Allan W., and Bruce E. Hansen. 1996. Residual-based tests for cointegration in models with regime shifts. Journal of Econometrics 70: 99-126. [CrossRef]

Haron, Sudin, and Wan Nursofiza Wan Azmi. 2008. Determinants of Islamic and conventional deposits in the Malaysian Banking system. Managerial Finance 34: 618-43. [CrossRef]

Hassan, Olanrewaju Makinde. 2016. Effect of Interest Rate on Commercial Bank Deposits in Nigeria (2000-2013). Paper presented at the First American Academic Research Conference on Global Business, Economics, Finance and Social Science, New York, NY, USA, May 25-28.

Ibrahim, Mansor H. 2006. Stock prices and bank loan dynamics in a developing country: The case of Malaysia. Journal of Applied Economics 9: 71-89. [CrossRef]

Johansen, Søren. 1988. Statistical analysis of cointegration vectors. Journal of Economic Dynamics and Control 12: 231-54. [CrossRef]

Johansen, Søren. 1991. Estimation and hypothesis testing of cointegration vectors in Gaussian vector autoregressive models. Econometrica: Journal of the Econometric Society 59: 1551-80. [CrossRef]

Karim, Bakri Abdul, Zulkefly Abdul Karim, and Muhammad Hafiz Mohd Shukri. 2017. Determinants of Islamic Bank financing in Malaysia: An empirical study using linear and nonlinear ARDL model. Jurnal Ekonomi Malaysia 51: 15-22.

Kasri, Rahmatina, and Salina Hj Kassim. 2009. Empirical determinants of saving in the Islamic banks: Evidence from Indonesia. Journal of King Abdulaziz University: Islamic Economics 22: 181-201.

Kassim, Salina H., M. Shabri Abd Majid, and Rosylin Mohd Yusof. 2009. Impact of monetary policy shocks on the conventional and Islamic banks in a dual banking system: Evidence from Malaysia. Journal of Economic Cooperation and Development 30: 41-58.

Kim, Sun Bae, and Ramon Moreno. 1994. Stock prices and bank lending behavior in Japan. Economic Review-Federal Reserve Bank of San Francisco 1: 31-42.

Lindgren, Carl-Johan, Gillian G. Garcia, and Matthew I. Saal. 1996. Bank Soundness and Macroeconomic Policy. Washington: International Monetary Fund.

Loayza, Norman, and Rashmi Shankar. 2000. Private saving in India. The World Bank Economic Review 14: 571-94. [CrossRef]

Mobin, Mohammad Ashraful, and Mansur Masih. 2016. Do the Macroeconomic Variables Have Any Impact on the Islamic Bank Deposits? An Application of ARDL Approach to the Malaysian Market. Available online: https://mpra.ub.uni-muenchen.de/62342/ (accessed on 10 April 2019).

Mushtaq, Saba, and Danish Ahmed Siddiqui. 2017. Effect of interest rate on bank deposits: Evidences from Islamic and non-Islamic economies. Future Business Journal 3: 1-8. [CrossRef]

Nurrachmi, Rininta, Mia Fathia, Ashanee Mad-ahdin, Ninasrin Radenarmad, and Ruli Akhtar. 2012. Time Value of Money in Islamic Perspective and the Practice in Islamic Banking Implications. Available online: http://mpra.ub.uni-muenchen.de/46818/ (accessed on 10 April 2019). 
Nursyamsiah, Tita. 2017. Macroeconomic determinants of Islamic banking financing. Tazkia Islamic Finance and Business Review 11: 145-64. [CrossRef]

Ojeaga, Paul, Daniel Ojeaga, and Deborah O. Odejimi. 2016. The Impact of Interest Rate on Bank Deposits: Evidences from the Nigerian Banking Sector. Available online: https://mpra.ub.uni-muenchen.de/53238/ (accessed on 10 April 2019).

Ostadi, Hossein, and Ali Sarlak. 2014. Effective factors on the absorption of bank deposits in order to increase the relative share of Isfahan Sepah Bank. International Journal of Academic Research in Economics and Management Sciences 3: 139-49. [CrossRef]

Pesaran, M. Hashem, and Yongcheol Shin. 1998. An autoregressive distributed lag modeling approach to cointegration. Econometric Society Monographs 31: 371-413.

Pesaran, M. Hashem, Yongcheol Shin, and Richard J. Smith. 2001. Bounds testing approaches to the analysis of level relationships. Journal of Applied Econometrics 16: 289-326. [CrossRef]

Pham, Thi Hong Hanh. 2015. Determinants of Bank Lending. Available online: https://hal.archives-ouvertes.fr/ hal-01158241/document (accessed on 10 April 2019).

Phillips, P.C.B., and S. Oualiaris. 1990. Asymptotic properties of residual based tests for cointegration. Econometrica 58: 165-93. [CrossRef]

Pruteanu-Podpiera, Anca Maria. 2007. The role of banks in the Czech monetary policy transmission mechanism. Economics of Transition 15: 393-428. [CrossRef]

Siaw, Otu Larbi, and Peter Angmor Lawer. 2015. Determinants of bank deposits in Ghana: A cointegration approach. Asian Journal of Economics and Empirical Research 2: 1-7.

Solarin, Sakiru A., Shawkat Hammoudeh, and Muhammad Shahbaz. 2018. Influence of Economic Factors on Disaggregated Islamic Banking Deposits: Evidence with Structural Breaks in Malaysia. Journal of International Financial Markets, Institutions and Money 55: 13-28. [CrossRef]

Sukmana, Raditya, and Salina H. Kassim. 2010. Roles of the Islamic banks in the monetary transmission process in Malaysia. International Journal of Islamic and Middle Eastern Finance and Management 3: 7-19. [CrossRef]

Tariq, Anam, and Mansur Masih. 2016. Risk-Sharing Deposits in Islamic banks: Do Interest Rates Have Any Influence on Them? Available online: https://mpra.ub.uni-muenchen.de/71680/ (accessed on 10 April 2019).

Yuksel, Serhat, Shahriyar Mukhtarov, Elvin Mammadov, and Mustafa Özsarı. 2018. Determinants of profitability in the banking sector: An analysis of post-soviet countries. Economies 6: 41. [CrossRef]

Zivot, Eric, and Donald W. K. Andrews. 1992. Further evidence on the great crash, the oil-price shock, and the unit-root hypothesis. Journal of Business \& Economic Statistics 10: 251-70. 